\title{
Response of Two Wheat Cultivars to Supplemental Nitrogen under Different Salinity Stress
}

\author{
A. L. Saleh ${ }^{1}$, A. A. Abd El-Kader ${ }^{2} \&$ A. K. Alva ${ }^{3}$ \\ ${ }^{1}$ Plant Nutrition Department, National Research Centre, Egypt \\ ${ }^{2}$ Soils and Water Use Department, National Research Centre, Egypt \\ ${ }^{3}$ Northern Plains Agricultural Research Laboratory, United States Department of Agriculture, Agricultural \\ Research Service, Sidney, MT, USA \\ Correspondence: A. K. Alva, Northern Plains Agricultural Research Laboratory, United States Department of \\ Agriculture, Agricultural Research Service, Sidney, MT 59270, USA. E-mail: ashok.alva@ars.usda.gov
}

Received: March 4, $2015 \quad$ Accepted: April 16, $2015 \quad$ Online Published: May 15, 2015
doi:10.5539/jas.v7n6p14
URL: http://dx.doi.org/10.5539/jas.v7n6p14

\begin{abstract}
Effects of supplemental nitrogen (N), as either farmyard manure (FYM) or urea, on response of two wheat (Triticum aestivum) cultivars (a salt sensitive 'Sakha 69' and a salt tolerant 'Sakha 93') were investigated in a green house experiment under various salinity levels (control, 6, 9, or $12 \mathrm{dS} \mathrm{m}^{-1}$ ). Grain and straw yields of both cultivars decreased with an increase in salinity levels. Supplamental N application, using FYM or urea, mitigated the adverse effects of salinity only at the low salinity level $\left(6 \mathrm{dS} \mathrm{m}^{-1}\right)$. This effect was greater in a salt tolerant cultivar (Sakha 93) than that in a salt sensitive cultivar (Sakha 69). At the moderate and high salinity (9 and 12 $\mathrm{dS} \mathrm{m}^{-1}$ ) levels the supplemental $\mathrm{N}$ had no beneficial effects in mitigating the salinity stress of both cultivars. The mean grain yields, across all salinity levels and cultivars, of the plants received FYM and urea were greater by 11 , and $8 \%$, respectively, as compared to that of the plants received no supplemental N. The corresponding values for straw were 12 and 7\%. The concentrations of N, P and K in the grain and straw significantly decreased with increasing salinity levels. Concentrations of $\mathrm{Na}, \mathrm{Cl}$, and $\mathrm{Ca}$ in the grain and straw were greater in salt sensitive cultivar than those in a salt tolerant cultivar. Concentrations of these elements significantly increased with an increase in salinity levels. This study demonstrated that supplemental N, as either FYM or as Urea, can mitigate negative effects of mild salinity stress, and that this beneficial effect was greater in a salt tolerant cultivar as compared to that in a salt sensitive cultivar.
\end{abstract}

Keywords: abiotic stress, salinity, nitrogen sources, farm yard manure, mineral nutrition, Triticum aestivum

\section{Introduction}

Soil salinity is a serious problem in Egypt with upto $33 \%$ of the cultivated land impacted by high salinity due to low precipitation ( $<25 \mathrm{~mm}$ annual rainfall) and irrigation with saline water (El-Hendawy et al., 2005). Salinity is the major environmental factor limiting plant growth and productivity worldwide (Munns, 2002). The negative effects of salinity on plant growth may be associated to an increase in the osmotic potential of the soil solution that reduces plant available water, or increase in concentrations of certain ions that inhibits plant metabolism (Onani, 2005).

Wheat is the most important cereal crop in Egypt, however, domestic wheat production supplies only $40 \%$ of the demand. Increasing wheat production is a priority to maintain food security. Therefore, it is important to develop crop management alternatives to overcome the salinity stress, hance increase total wheat production.

Nitrogen $(\mathrm{N})$ plays a vital nutritional and physiological role in plants. Plants can take up $\mathrm{N}$ as an anion (nitrate) or as cation (ammonium). Plant tolerance to high salt content in the growth medium may increase, decrease or remain unchanged with increasing rates of nutrients applications depending on the specific experimental conditions, including the level of salt stress (Irshad et al., 2002a). Therefore, the objective of this study was to evaluate the effects of different sources of supplemental $\mathrm{N}$ on the response of wheat cultivars to different levels of salinity. 


\section{Materials and Methods}

Two wheat cultivars i.e. Sakha 93 (salt tolerant) and Sakha 69 (salt sensitive) were used. A pot experiment was conducted in a green house at the National Research Centre, Cairo, Egypt, using plastic pots of $30 \mathrm{~cm}$ height and $25 \mathrm{~cm}$ diameter with $8 \mathrm{~kg}$ clay loam soil $(0-30 \mathrm{~cm}$ depth) per pot. Some physical and chemical properties of the soil used in the study are shown in Table 1.

Table 1. Some physical and chemical properties of the soil used in this experiment

\begin{tabular}{|c|c|}
\hline Characteristics & Value \\
\hline \multicolumn{2}{|l|}{ Particle size distribution } \\
\hline Coarse sand (mg/g) & 70.0 \\
\hline Fine sand $(\mathrm{mg} / \mathrm{g})$ & 200.0 \\
\hline Silt (mg/g) & 350.0 \\
\hline Clay (mg/g) & 380.0 \\
\hline Textural class & Clay loam \\
\hline $\mathrm{pH}(1: 2.5)$ & 7.4 \\
\hline $\operatorname{ECe}\left(\mathrm{dS} \mathrm{m}^{-1}\right)$ & 1.3 \\
\hline \multicolumn{2}{|l|}{ Soluble cations $($ meq $/ L)$} \\
\hline Calcium & 4.9 \\
\hline Magnesium & 3.5 \\
\hline Potassium & 0.7 \\
\hline Sodium & 4.7 \\
\hline \multicolumn{2}{|l|}{$\underline{\text { Soluble anions }(\mathrm{meq} / L)}$} \\
\hline Carbonate & 0.0 \\
\hline Bicarbonate & 8.1 \\
\hline Chloride & 3.2 \\
\hline Sulphate & 2.6 \\
\hline Organic matter $(\%)$ & 1.8 \\
\hline Calcium Carbonate $(\%)$ & 3.6 \\
\hline \multicolumn{2}{|l|}{ Available Nutrients } \\
\hline Nitrogen (ppm) & 76 \\
\hline phosphorus (ppm) & 18 \\
\hline potassium (ppm) & 160 \\
\hline
\end{tabular}

Table 2. Some properties of the farmyard manure used in the study

\begin{tabular}{lllllllll}
\hline \multirow{2}{*}{$\mathrm{pH}(1: 10)$} & \multirow{2}{*}{$\mathrm{EC}\left(\mathrm{dS} \mathrm{m}^{-1}\right)(1: 10)$} & \multirow{2}{*}{$\mathrm{OM}(\%)$} & \multirow{2}{*}{$\mathrm{OC}(\%)$} & $\mathrm{C} / \mathrm{N}$ ratio & \multicolumn{4}{c}{ Concentrations of $(\%)$} \\
\cline { 5 - 8 } & & & & $\mathrm{N}$ & $\mathrm{P}$ & $\mathrm{K}$ & $\mathrm{Ca}$ \\
\hline 7.64 & 7.50 & 35.5 & 20.64 & 21.5 & 0.96 & 0.29 & 2.15 & 0.32 \\
\hline
\end{tabular}

All pots received uniform rates of fertilizer application prior to sowing, i.e. 0.6, 0.8, and $0.4 \mathrm{~g}$ of urea, single superphosphate and potassium sulphate, respectively, which is equivalent to 180,240 , and $120 \mathrm{~kg} / \mathrm{ha} \mathrm{N}$, $\mathrm{P}$, and $\mathrm{K}$, respectively. Ten seeds were planted per pot. $\mathrm{N}$ topdressing was done three weeks after sowing using urea at $\mathrm{N}$ rate equivalent to $180 \mathrm{~kg} / \mathrm{ha}$.

Treatments included three salinity levels of 6,9 , and $12 \mathrm{dS} \mathrm{m}^{-1}$ using 1:1 ratio of $\mathrm{NaCl}^{-\mathrm{CaCl}_{2}}$. A control treatment with no added salinity was also included with an initial soil salinity of $1.3 \mathrm{dS} \mathrm{m}^{-1}$. Subtreatments were supplemental $\mathrm{N}$ sources: i.e. (i) farmyard manure $81.63 \mathrm{~g} /$ pot before sowing (equivalent to $48 \mathrm{Mg} / \mathrm{ha}$, at $0.96 \%$ $\mathrm{N}$ in FYM, total $\mathrm{N}$ application was $460 \mathrm{~kg} / \mathrm{ha}$ ); (ii) urea at $1.8 \mathrm{~g} /$ pot equivalent to $540 \mathrm{~kg} / \mathrm{ha}$ applied in three doses, i.e. before sowing, and 3 and 5 weeks after sowing; (iii) no supplemental $\mathrm{N}$, as a control. The experiment was conducted with four replications. Some properties of the farmyard manure used in this study are shown in Table 2. 
Plants were harvested 150 days after sowing (maturity stage, late November 2011). Dry weights of straw and grain per pot were recorded. Concentrations of $\mathrm{N}, \mathrm{P}, \mathrm{K}, \mathrm{Na}, \mathrm{Ca}$, and $\mathrm{Cl}$ in the straw and grian were analyzed following the procedure reported by Cottenie et al. (1982). Effects of treatments on plant response parameters were evaluated by analysis of variance (ANOVA) and mean separation test using SAS program (SAS, 1991).

\section{Results and Discussion}

\subsection{Grain and Straw Yield}

The grain and straw yields were significantly influenced by the cultivar, salinity levels as well as supplemental $\mathrm{N}$ treatments (Table 3). Only salinity X supplemental $\mathrm{N}$ interaction effect was significant on the grain yield. Straw yield, however, was significantly influenced by all two way interactions. The mean grain and straw yields, across both salinity and supplemental $N$ treatments, were significantly greater for salt tolerant Sakha 93 cultivar as compared to those for a salt sensitive Sakha 69 cultivar (Table 4). The grain yields were 13.03, 12.31, 8.86, and $7.58 \mathrm{~g} /$ pot, while the straw yields were $14.95,11.46,9.52$, and $7.41 \mathrm{~g} /$ pot for control and salinity levels of 6,9 and $12 \mathrm{dS} \mathrm{m}^{-1}$, respectively.

Table 3. Analysis of variance (ANOVA) for single factor and interaction effects of cultivars (C), salinity levels $(\mathrm{S})$, and supplemental nitrogen $(\mathrm{N})$ treatments on response parameters of wheat cultivars

\begin{tabular}{|c|c|c|c|c|c|c|c|c|c|c|c|c|c|c|}
\hline \multirow{2}{*}{ Sources } & \multirow{2}{*}{$\begin{array}{l}\text { Grain } \\
\text { yield }\end{array}$} & \multirow{2}{*}{$\begin{array}{l}\text { Straw } \\
\text { Yield }\end{array}$} & \multicolumn{2}{|c|}{$\mathrm{Na}$} & \multicolumn{2}{|c|}{$\mathrm{Cl}$} & \multicolumn{2}{|c|}{$\mathrm{Ca}$} & \multicolumn{2}{|c|}{$\mathrm{N}$} & \multicolumn{2}{|c|}{$\mathrm{P}$} & \multicolumn{2}{|c|}{$\mathrm{K}$} \\
\hline & & & Grain & Straw & Grain & Straw & Grain & Straw & Grain & Straw & Grain & Straw & Grain & Straw \\
\hline \multicolumn{15}{|c|}{ Significance of $F$ test } \\
\hline $\mathrm{C}$ & $0.26^{*}$ & $0.19 *$ & $0.007^{*}$ & $0.025^{*}$ & $0.014 *$ & $0.049^{*}$ & NS & $0.039^{*}$ & $0.024 *$ & $0.024 *$ & $0.015^{*}$ & $0.012^{*}$ & $0.016^{*}$ & $0.057^{*}$ \\
\hline $\mathrm{S}$ & $0.37 *$ & $0.27 *$ & $0.01 *$ & $0.036^{*}$ & $0.02 *$ & $0.069^{*}$ & $0.020^{*}$ & $0.054 *$ & $0.068^{*}$ & $0.035^{*}$ & $0.020^{*}$ & $0.018^{*}$ & $0.023^{*}$ & $0.080^{*}$ \\
\hline $\mathrm{N}$ & $0.32 *$ & $0.23 *$ & NS & $0.03 *$ & $0.016^{*}$ & $0.059^{*}$ & NS & $0.047^{*}$ & $0.059 *$ & $0.030^{*}$ & NS & $0.016^{*}$ & NS & $0.070^{*}$ \\
\hline $\mathrm{CxS}$ & NS & $0.38^{*}$ & $0.016^{*}$ & $0.051^{*}$ & $0.027^{*}$ & $0.098^{*}$ & $0.03 *$ & $0.077^{*}$ & $0.096^{*}$ & $0.049^{*}$ & $0.028^{*}$ & NS & NS & NS \\
\hline SxN & $0.63^{*}$ & $0.47 *$ & NS & NS & NS & NS & NS & NS & NS & $0.060^{*}$ & $0.015^{*}$ & NS & NS & NS \\
\hline $\mathrm{CxN}$ & NS & $0.33 *$ & NS & NS & NS & NS & NS & NS & NS & NS & NS & NS & NS & NS \\
\hline $\mathrm{CxSxN}$ & NS & NS & NS & NS & NS & NS & NS & Ns & NS & NS & NS & NS & NS & NS \\
\hline
\end{tabular}

Note. $\mathrm{NS}=$ non significant $; *$ = significant at $\mathrm{P} \geq 95 \%$.

Table 4. Effects of cultivars, salinity levels, and supplemental nitrogen sources on grain and straw yields of wheat cultivars and concentrations of selected mineral elements in grain and straw

\begin{tabular}{|c|c|c|c|c|c|c|c|c|c|c|c|c|c|c|}
\hline \multirow{2}{*}{ Variables } & \multirow{2}{*}{$\begin{array}{l}\text { Grain } \\
\text { yield }\end{array}$} & \multirow{2}{*}{$\begin{array}{l}\text { Straw } \\
\text { Yield }\end{array}$} & \multicolumn{2}{|c|}{$\mathrm{Na}$} & \multicolumn{2}{|c|}{$\mathrm{Cl}$} & \multicolumn{2}{|c|}{$\mathrm{Ca}$} & \multicolumn{2}{|c|}{$\mathrm{N}$} & \multicolumn{2}{|c|}{$\mathrm{P}$} & \multicolumn{2}{|c|}{$\mathrm{K}$} \\
\hline & & & Grain & Straw & Grain & Straw & Grain & Straw & Grain & Straw & Grain & Straw & Grain & Straw \\
\hline & -----g & ---- & - & & & 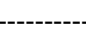 & ----Pe & it & $\Lambda(w / w)$ & -1 & . & & & ----- \\
\hline \multicolumn{15}{|l|}{ Cultivars: } \\
\hline Sakha $93^{\#}$ & $11.27 \mathrm{a}$ & $11.86 \mathrm{a}$ & $0.06 \mathrm{~b}$ & $0.69 \mathrm{~b}$ & $0.15 \mathrm{~b}$ & $2.45 \mathrm{~b}$ & $0.36 \mathrm{a}$ & $2.24 \mathrm{~b}$ & $2.44 \mathrm{~b}$ & $0.55 \mathrm{a}$ & $0.36 \mathrm{a}$ & $0.21 \mathrm{a}$ & $0.52 \mathrm{a}$ & $2.90 \mathrm{a}$ \\
\hline Sakha $69^{S}$ & $9.63 \mathrm{~b}$ & $9.81 \mathrm{~b}$ & $0.09 \mathrm{a}$ & $0.91 \mathrm{a}$ & $0.18 \mathrm{a}$ & $2.94 \mathrm{a}$ & $0.35 \mathrm{a}$ & $2.32 \mathrm{a}$ & $2.47 \mathrm{a}$ & $0.47 \mathrm{~b}$ & $0.34 \mathrm{~b}$ & $0.19 b$ & $0.48 \mathrm{~b}$ & $2.83 \mathrm{~b}$ \\
\hline \multicolumn{15}{|l|}{ Salinity: } \\
\hline Control $^{\&}$ & $13.03 \mathrm{a}$ & $14.95 \mathrm{a}$ & $0.04 \mathrm{c}$ & $0.25 \mathrm{~d}$ & $0.12 \mathrm{~d}$ & $1.45 \mathrm{~d}$ & $0.28 \mathrm{~d}$ & $2.11 \mathrm{~d}$ & $2.89 \mathrm{a}$ & $0.77 \mathrm{a}$ & $0.42 \mathrm{a}$ & $0.22 b$ & $0.56 \mathrm{a}$ & $3.47 \mathrm{a}$ \\
\hline 6 & $12.31 \mathrm{~b}$ & $11.46 \mathrm{~b}$ & $0.05 \mathrm{c}$ & $0.61 \mathrm{c}$ & $0.15 \mathrm{c}$ & $2.39 \mathrm{c}$ & $0.33 \mathrm{c}$ & $2.19 \mathrm{c}$ & $2.45 b$ & $0.53 b$ & $0.39 b$ & $0.24 \mathrm{a}$ & $0.54 \mathrm{a}$ & $2.91 \mathrm{~b}$ \\
\hline 9 & $8.86 \mathrm{c}$ & $9.52 \mathrm{c}$ & $0.08 \mathrm{~b}$ & $0.98 \mathrm{~b}$ & $0.18 \mathrm{~b}$ & $3.13 b$ & $0.38 \mathrm{~b}$ & $2.36 \mathrm{~b}$ & $2.34 \mathrm{c}$ & $0.40 \mathrm{c}$ & $0.31 \mathrm{c}$ & $0.19 b$ & $0.47 \mathrm{~b}$ & $2.62 \mathrm{c}$ \\
\hline 12 & $7.58 \mathrm{~d}$ & $7.41 \mathrm{~d}$ & $0.12 \mathrm{a}$ & $1.36 \mathrm{a}$ & $0.21 \mathrm{a}$ & $3.82 \mathrm{a}$ & $0.43 a$ & $2.47 \mathrm{a}$ & $2.16 \mathrm{~d}$ & $0.35 \mathrm{~d}$ & $0.28 \mathrm{~d}$ & $0.16 \mathrm{c}$ & $0.44 \mathrm{c}$ & $2.46 \mathrm{~d}$ \\
\hline \multicolumn{15}{|l|}{$\underline{N}$} \\
\hline $\begin{array}{l}\text { sources: } \\
\text { Control }^{\circledR}\end{array}$ & 9.7 & 10.1 & 0.07 & 0.7 & 0.1 & 2.6 & 0.3 & 2.3 & 2. & $0.45 \mathrm{c}$ & $0.34 \mathrm{a}$ & $0.18 \mathrm{c}$ & $0.50 \mathrm{a}$ & $2.79 \mathrm{c}$ \\
\hline FYM & $10.99 \mathrm{a}$ & $11.49 \mathrm{a}$ & $0.075 \mathrm{a}$ & $0.84 \mathrm{a}$ & $0.16 a b$ & $2.87 \mathrm{a}$ & $0.36 a$ & $2.15 \mathrm{c}$ & $2.50 \mathrm{a}$ & $0.56 \mathrm{a}$ & $0.35 \mathrm{a}$ & $0.23 \mathrm{a}$ & $0.52 \mathrm{a}$ & $2.94 a$ \\
\hline Urea & $10.59 \mathrm{~b}$ & $10.87 \mathrm{~b}$ & $0.073 \mathrm{a}$ & $0.80 \mathrm{~b}$ & $0.15 b$ & $2.71 \mathrm{~b}$ & $0.36 \mathrm{a}$ & $2.32 \mathrm{~b}$ & $2.45 \mathrm{ab}$ & $0.52 b$ & $0.34 \mathrm{a}$ & $0.20 \mathrm{~b}$ & $0.50 \mathrm{a}$ & $2.87 \mathrm{~b}$ \\
\hline
\end{tabular}

Note. *Means followed by similar letters are not significantly different $(\mathrm{P}>95 \%)$, by each column and by each variable; ${ }^{\#}$ Salt tolerant; ${ }^{\$}$ Salt sensitive; ${ }^{\&}$ No added salinity; ${ }^{\circledR}$ No Supplemental N. 
Supplamental N, regardless of sources, increased the grain and straw yields of both cultivars only under no salinity or at the low salinity $\left(6 \mathrm{dS} \mathrm{m}^{-1}\right)$ treatments (Figures 1 and 2). At the high salinity treatments $(9$ and $12 \mathrm{dS}$ $\mathrm{m}^{-1}$ ) supplemental $\mathrm{N}$ failed to provide any benificial effects of mitigating the negative effects of salinity. The magnitude of beneficial effects of supplemental $\mathrm{N}$ as compared to no supplemental $\mathrm{N}$ was greater in Sakha 93 than that in Sakha 69 cultivar. This is somewhat expected in line with the physiological difference among the cultivars, i.e. mitigation of negative effects of salinity by an external treatment is often greater for a salinity tolerant cultivar as compared to that for a sensitive cultivar. The grain yield increases were 11 and $8 \%$ For FYM and urea as compared to that for control, respectively, while the corresponding values for straw were 12 and $7 \%$. The results are consistent with the findings of Sushila and Giri (2000), Uyanoz et al. (2006), and Bayu et al. (2006).

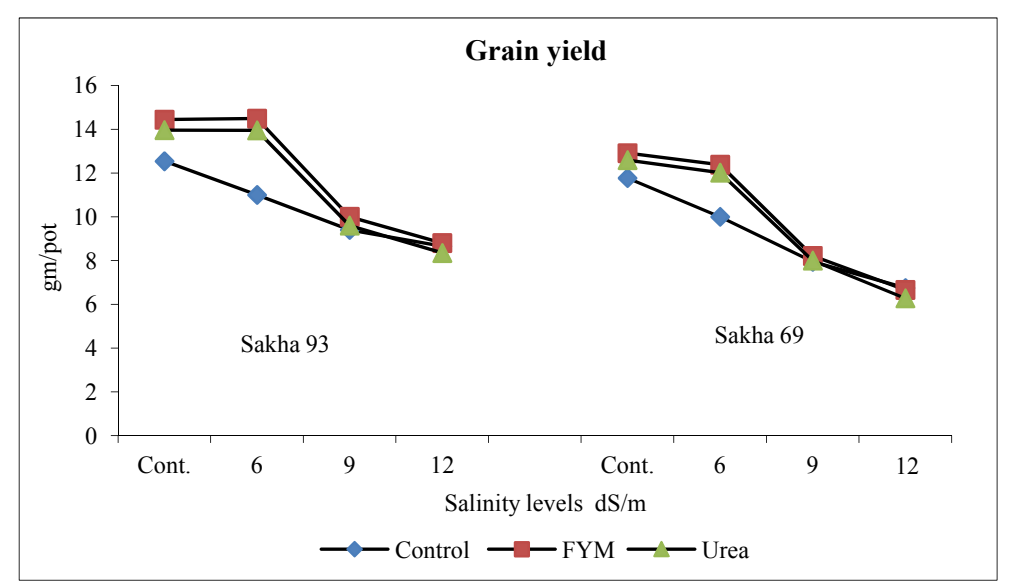

Figure 1. Effects of salinity levels and supplemental $\mathrm{N}$ treatments on grain yield of a salt tolerant (Sakha 93) and a salt sensitive (Sakha 69) wheat cultivars

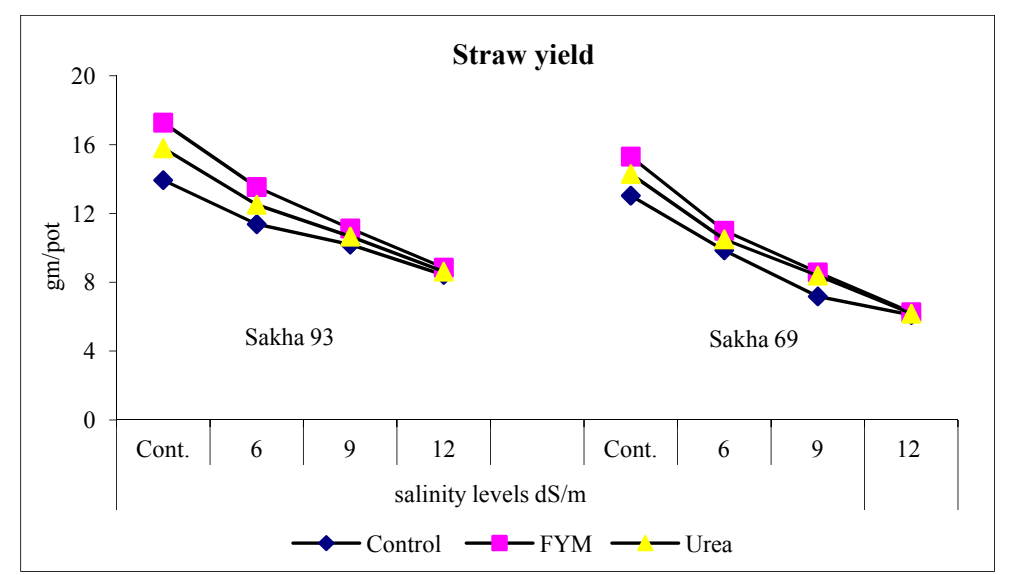

Figure 2. Effects of salinity levels and supplemental $\mathrm{N}$ treatments on straw yield of a salt tolerant (Sakha 93) and a salt sensitive (Sakha 69) wheat cultivars

The adverse effects of salinity were greater for Sakha 69 as compared to that for Sakha 93 . The grain yield reductions at the highest salinity level as compared to that with the control were $47.2 \%$ and $36.9 \%$ for Sakha 69 and Sakha 93, respectively. The corresponding values for straw were $56.5 \%$ and $44.9 \%$. Ahmed et al. (2005) reported $14 \%$ decrease in grain yield of salt tolerant wheat cultivar (LU 26S) with an increase in salinity level to $12.7 \mathrm{dS} \mathrm{m}^{-1}$ as compared to $52 \%$ decrease for a salt sensitive cultivar (SRC 3).

\subsection{Concentrations of $\mathrm{Na}, \mathrm{Cl}$ and Macronutrients in Grain and Straw}

Concentrations of $\mathrm{Na}$ and $\mathrm{Cl}$ increased significantly in the grain and straw with an increase in salinity levels (Tables 3 and 4). The magnitude of increase was greater in the straw as compared to that in grain. This trend is in accordance with the finding of Ahmedi et al. (2009). Concentrations of $\mathrm{Na}$ and $\mathrm{Cl}$, in both grain and straw were 
significantly greater in the salt sensitive Sakha 69 cultivar as compared to those in a tolerant cultivar Sakha 93 (Table 4). These results are in agreement with the findings of Schachtman and Munns (1992).

Increasing soil salinity levels significantly increased $\mathrm{Ca}$ concentrations in both grain and straw. Calcium concentrations in the grain were $0.28,0.33,0.38$, and $0.43 \%$ with salinity treatments of control, 6,9 , and $12 \mathrm{dS}$ $\mathrm{m}^{-1}$, respectively, while the corresponding values in the straw were $2.11,2.19,2.36$ and $2.47 \%$. This could be attributable to increased $\mathrm{Ca}$ availability with increasing salinity levels that was achieved by using 1:1 ratio of $\mathrm{NaCl}: \mathrm{CaCl}_{2}$. Furthermore, the reduction in both grain and straw yields with an increase in salinity levels also contribute to an increase in $\mathrm{Ca}$ concentrations on dry matter basis. Ca concentration in the straw was significantly greater in Sakha 69 (2.32\%) as compared to that in Sakha 93 (2.24\%). On the other hand, there was no significant difference between the two cultivars with respect to $\mathrm{Ca}$ concentrations in the grain.

Concentrations of N, P, K in both grain and straw decreased with an increase in salinity levels from control to 12 $\mathrm{dS} \mathrm{m}^{-1}$ (Table 4). The adverse effects of salinity on $\mathrm{N}$ concentration could be attributed to the presence of high amount of chloride which could decrease N uptake as reported by Saneoka, et al. (1999) and Uyanoz et al. (2006). Supplamental N application as FYM or Urea increased N concentration in the grain and straw. Concentrations of macronutrients in the grain and straw were greater in Sakha 93 as compared to those in Sakha 69, except the concentration of $\mathrm{N}$ in grain. The trend was reverse for the latter. El-Agroudi et al. (2005) reported greater $\mathrm{N}$ uptake by a salt tolerant wheat cultivar as compared to that by a salt sensitive cultivar.

Nitrogen concentration in the straw decreased significantly with increasing salinity levels, across both supplemental $\mathrm{N}$ and no supplemental $\mathrm{N}$ treatments. El-shafie et al. (2003) reported a significant increase in $\mathrm{N}$ uptake by wheat plants grown under saline condition with addition of FYM. Navarro et al. (2001) stated that phosphorus availability is reduced in saline soils because phosphate concentration in the soil solution is controlled by Ca-P interaction.

The concentrations of $\mathrm{K}$ in the grain and straw decreased with an increase in salinity levels (Table 4). This could be attributable to an antagonism for $\mathrm{K}$ uptake by an increase in $\mathrm{Na}$ and $\mathrm{Ca}$ availabity in the soil, since salinity increase was achieved by using $\mathrm{NaCl}$ and $\mathrm{CaCl}_{2}$. Such antagonism for cation uptake was reported by Mostafa (2001) and Ahmedi et al. (2009).

Supplamental $\mathrm{N}$ application had no significant effects on $\mathrm{K}$ concentrations in the grain, but significantly increased $\mathrm{K}$ concentrations in the straw as compared to that of the plants with no supplemental $\mathrm{N}$. This positive effect was greater with application of FYM than that with application of urea. These results are consistent with the findings of Hassan and Mostafa (2002), El-Shafie et al. (2003), and Irshad et al. (2002b).

\section{References}

Ahmadi, A., Eman, Y., \& Pessarakli, M. (2009). Response of various cultivars of wheat and maize to salinity stress. Journal food Agriculture and Environment, 7, 123-128.

Ahmed, M., Niazi, B. H., Zaman, B., \& Athar, M. (2005). Varietals differences in agronomic performance of six wheat varieties grown under saline field environment. International Journal of Environmental Science and Technology, 2, 49-57. http://dx.doi.org/10.1007/BF03325857

Bayu, W., Rethman, N. F. G., Hammes, P. S., \& Alemu, G. (2006). Effects of Farmyard Manure and Inorganic Fertilizers on Sorghum Growth, Yield, and Nitrogen Use in a Semi-Arid Area of Ethiopia. Journal of Plant Nutrition, 29, 391-407. http://dx.doi.org/10.1080/01904160500320962

Cottenie, A., Verloo, L., Kiens, L., Velghe, G., \& Camerlynch, R. (1982). Chemical analysis of plant and soils. Lab. of analytical and agro chemistry, State University of Ghent, Belgium.

El-Hendawy, S. E., Hu, Y., Yakout, G. M., Awad, A. M., Hafiz, S. E., \& Schmidhalter, U. (2005). Evaluating salt tolerance of wheat genotypes using multiple parameters. Europian Journal of Agronomy, 22, 243-253. http://dx.doi.org/10.1016/j.eja.2004.03.002

El-Agroudi, M. W. M., Labeeb, G., Abd El-Hadi, M. R., \& Abdou, T. A. M. (2005). Influence of soil salinity on nutrients uptake, yield and yield component of two wheat varieties. Journal of Agricultural Science Mansoura University, 30, 5689-5700.

El-shafie, F. S., \& El-Shikha, S. A. (2003). Productivity and nutrients uptake of wheat and faba bean grown on cancerous soil as affected by water. Minufiya Journal of Agricultural Research, 28, 1025-1048.

Hassan, M. A. M., \& Mostafa, M. M. (2002). Uptake of nutrients and heavy metals by barley plant grown on sandy and calcareous soils as affected by irrigation water salinity and sewage addition. Zagazig Journal of Agricultural Research, 29, 1929-1950. 
Irshad, M., Honna, T., Eneji, A. E., \& Yamamoto, S. (2002a). Wheat response to nitrogen source under saline conditions. Journal of Plant Nutrition, 25, 2603-2612. http://dx.doi.org/10.1081/PLN-120015525

Irshad, M., Yamamoto, S., Eneji, A. E., Endo, T., \& Honna, T. (2002b). Urea and manure effect on growth and mineral contents of maize under saline conditions. Journal of Plant Nutrition, 25, 189-200. http://dx.doi.org/10.1081/PLN-100108790

Mostafa, M. M. (2001). Nutrient uptake and dry matter yield of barley as affected by salinity of irrigation water and addition of organic materials. Zagazig Journal of Agricultural Research, 28, 533-552.

Munns, R. (2002). Comparative physiology of salt and water stress. Plant Cell and Environment, 25, 239-250. http://dx.doi.org/10.1046/j.0016-8025.2001.00808.x

Navarro, J. M., Botella, M. A., Cerda, A., \& Martinez, V. (2001). Phosphorus uptake and translocation in salt stressed melon plants. Journal of plant physiology, 158, 375-381. http://dx.doi.org/10.1078/0176-1617-00147

Onani, E. N. (2005). Response of amaranth to salinity stress (Ph.D. thesis, p. 119). Faculty of Agriculture, University of Pretoria.

Saneoka, H., Shiota, K., Kurban, H., Chaudhary, M. I., Premachandra, G. S., \& Fujita, K. (1999). Effect of salinity on growth and solute accumulation in two wheat lines differing in salt tolerance. Soil Science Plant Nutrition, 45, 873-880. http://dx.doi.org/10.1080/00380768.1999.10414336

SAS Statistical Analysis System, Institute. (1991). SAS Users guide (Version 8) SAS Inst. Cary, N.C.

Sushila, R., \& Giri, G. (2000). Influence of farmyard manure, nitrogen and biofertilizers on growth, yield attributes and yield of wheat (Triticum aestivum) under limited water supply. Indian Journal of Agronomy, 45, 590-595.

Schachtman, D. P., \& Munns, R. (1992). Sodium accumulation in leaves for Triticum species that differ in salt tolerance. Australian Journal of Plant Physiology, 19, 331-340. http://dx.doi.org/10.1071/PP9920331

Uyanöz, R., Çetin, Ü., \& Karaarslan, E. (2006). Effect of Organic Materials on Yields and Nutrient Accumulation of Wheat. Journal of Plant Nutrition, 29, 959-974. http://dx.doi.org/10.1080/01904160600651787

\section{Copyrights}

Copyright for this article is retained by the author(s), with first publication rights granted to the journal.

This is an open-access article distributed under the terms and conditions of the Creative Commons Attribution license (http://creativecommons.org/licenses/by/3.0/). 